This item was submitted to Loughborough's Research Repository by the author.

Items in Figshare are protected by copyright, with all rights reserved, unless otherwise indicated.

\title{
Quantifying energy demand reduction considering householder willingness to apply measures
}

PLEASE CITE THE PUBLISHED VERSION

https://doi.org/10.1080/09613218.2019.1630245

\section{PUBLISHER}

(C) Taylor and Francis

\section{VERSION}

AM (Accepted Manuscript)

\section{PUBLISHER STATEMENT}

This is an Accepted Manuscript of an article published by Taylor \& Francis in Building Research \& Information on 26 June 2019, available online: http://www.tandfonline.com/10.1080/09613218.2019.1630245.

\section{LICENCE}

CC BY-NC-ND 4.0

\section{REPOSITORY RECORD}

Cosar-Jorda, Paula, Richard Buswell, and Val Mitchell. 2019. "Quantifying Energy Demand Reduction Considering Householder Willingness to Apply Measures”. figshare. https://hdl.handle.net/2134/38213. 


\section{Quantifying energy demand reduction considering householder willingness to apply measures}

P.Cosar-Jorda ${ }^{1}$, R.A.Buswell ${ }^{1}$, V.A.Mitchell ${ }^{2}$

${ }^{I}$ School of Architecture, Building and Civil Engineering, Loughborough University, Loughborough, UK

${ }^{2}$ Loughborough Design School, Loughborough University, Loughborough, UK

E-mails: p.cosar-jorda@lboro.ac.uk, r.a.buswell@lboro.ac.uk and v.a.mitchell@lboro.ac.uk

Corresponding author: r.a.buswell@lboro.ac.uk

Postal address:

School of Architecture, Building and Civil Engineering

Loughborough University

Ashby Road

Loughborough

Leicestershire LE11 3TU

Telephone number: +44 (0)1509 223783 


\begin{abstract}
Reducing energy demand in the domestic sector will be an important feature of future energy systems but is challenging to achieve in practice. Solutions lie in a range of building fabric and system improvements as well as adopting more sustainable routines and conceptions of normality in the home. The impact of such measures has so far been quantified without considering the willingness of the householder to adopt them. This paper uses a modelling approach to evaluate the effectiveness of technical and lifestyle measures to reduce energy demand in six households based on monitoring data and insights from interviews. The results are benchmarked against estimated tailored 2050 reduction targets and demonstrate that although these targets are achievable in the studied homes, householders might not always be willing to apply them. The resultant reduction pathways are shown to vary significantly between households, suggesting that bespoke strategies are needed to allow households to identify and select the most appropriate methods that allow them to maximise demand reduction.
\end{abstract}

\title{
Keywords
}

domestic energy demand reduction; retrofit; technology; lifestyle; user centred design; family homes. 


\section{Introduction}

The domestic sector consumes a significant amount of energy worldwide (Nejat, Jomehzadeh, Taheri, Gohari and Majid, 2015), accounting for $29 \%$ of the national demand in the UK (DECC, 2017). In order to achieve 2050 carbon targets, that require 80\% reduction in emissions from 1990 levels (Committee on Climate Change, 2015), domestic energy consumption needs to be reduced significantly alongside creating greater flexibility in supply in order to enable the electrification of heat (Baruah, Eyre, Qadrdan, Chaudry, Blainey, Hall, Jenkins and Tran, 2014; Clegg and Mancarella, 2018). Energy reduction through refurbishment and energy-efficiency measures have been the focus of many research and policy initiatives (Vadodaria, Loveday, Haines, Mitchell, Mallaband and Bayer, 2010; Department for Communities and Local Government, 2012). European policies aiming at reducing carbon emissions in the domestic sector include: mandatory energy certificates for buildings accompanying their sale and rental; energy efficiency standards and labelling for products such as boilers, appliances and lighting; the implementation of smart meters; protection of the consumer's right to receive easy access to their historical energy consumption with the intention of encouraging building retrofit; the updating of appliances and gadgets to more efficient ones; and provision of consumer advice on how to reduce consumption (Energy Saving Trust, 2015; European Commission, 2017).

The application of such measures often do not achieve the expected reductions (Abrahamse and Steg, 2011). In addition, recent European studies, indicate that current methods used to estimate a dwelling's fuel and $\mathrm{CO}_{2}$ savings through retrofit tend to overestimate savings, underestimate the payback time and possibly discourage costeffective, incremental improvements (ECCC, 2016). Similarly, the potential fuel and $\mathrm{CO}_{2}$ savings resulting from changes in occupant behaviour may well be far larger than is currently assumed (Sunikka-Blank and Galvin, 2012). 
Approaches that aim to maximise energy demand reduction have been studied from varying perspectives, particularly from social science and engineering with sociotechnical approaches increasingly favoured in order to understand the relationship between domestic energy consumption and householders' actions (Love and Cooper, 2015). Socio-technical research has raised awareness of the contextual complexity of daily practices in the home and the role they play in creating demand and reinforcing routines around energy use (Pink, Mackley and Morocsanu, 2015). Such studies have also highlighted how the implementation of reduction measures may lead to a shift in current practices, either due to the emergence of new interactions with technologies or systems, or indeed unintended changes to practices, for example, as a household renegotiates the meaning of comfort after the introduction of a new heating system (Hong, Gilbertson, Oreszczyn, Green and Ridley, 2009; Vadodaria, Loveday, Haines, Mitchell, Mallaband and Bayer, 2010). Despite the provision of feedback that highlights the potential for demand reduction, some domestic practices have been shown to be non-negotiable: for example due to 'perceived needs' to maintain levels of hygiene or comfort (Strengers, 2011). The reasons for households choosing to adopt a specific demand reduction measure are also complex as motivations for improving the home are likely to be impacted by an interplay of factors affecting decision making, including: aesthetics, lifestyle, life events, energy efficiency and finance (Haines, Mitchell and Mallaband, 2012).

This socio-technical study quantifies the potential reduction in energy demand in six family homes. A range of technical and 'lifestyle' measures were modelled for each household, where 'lifestyle' measures were defined as where demand reduction results from householders being prepared to accept a lower level of service with respect to comfort and convenience than currently provided (Shove, 2003). The approach can be 
applied to typical smart-meter equipment supplemented with home monitoring data and could be developed for wider application into an information service that quantifies the potential energy reduction for a specific home after considering the household's preferences and willingness to change.

\section{Method}

A practice orientated, user centred design (UCD) lens (Haines, Mitchell and Mallaband, 2010; Vadodaria, Loveday, Haines, Mitchell, Mallaband and Bayer, 2010) was used to understand the willingness of six households to adopt a range of energy reduction measures. This prioritised understanding of the habits of each household, associated routines and conceptions of normality when exploring which of the proposed measures they would be willing to adopt and why. It is assumed for the purposes of the study, that each household would choose to maintain current levels of service with respect to comfort and convenience if possible, whilst recognising that in the future, notions of what is considered normal in terms of service are likely to change (Shove, 2018).

The monitoring data, was used to tune a novel implementation of a steady-state heat balance model based on BREDEM (Building Research Establishment Domestic Energy Model, Henderson and Hart, (2012)) to evaluate the impact of a range of demand reduction measures on the energy consumption in individual households. The method is non-intrusive and is tailored to each household using monitoring data, which implicitly captures the influence of householder on energy demand, through the operation of appliances and systems. It is therefore effective when used to explore cause-and-affect relationships in a dwelling under normal use.

In this work, these results generated from the model were presented to the householders to generate feedback on their willingness to adopt and then the analysis 
was re-run with only the acceptable measures included to establish a more likely reduction potential.

The analysis was performed following the cycle process shown in Figure 1, where cycle 1 is: $1 \rightarrow 6$ and cycle 2 is $1 \rightarrow 2 \rightarrow 3 \rightarrow 4 \rightarrow 5 \rightarrow 6$.

In Cycle 1 - 'Data': monitoring data was used to implicitly capture the impact of household routines on energy consumption. 'Model': generated the annual impact of 16 reduction measures on energy demand. 'Results': the reduction potential was calculated under the most extreme measures to generate a 'theoretical limit' to the achievable energy demand reductions.

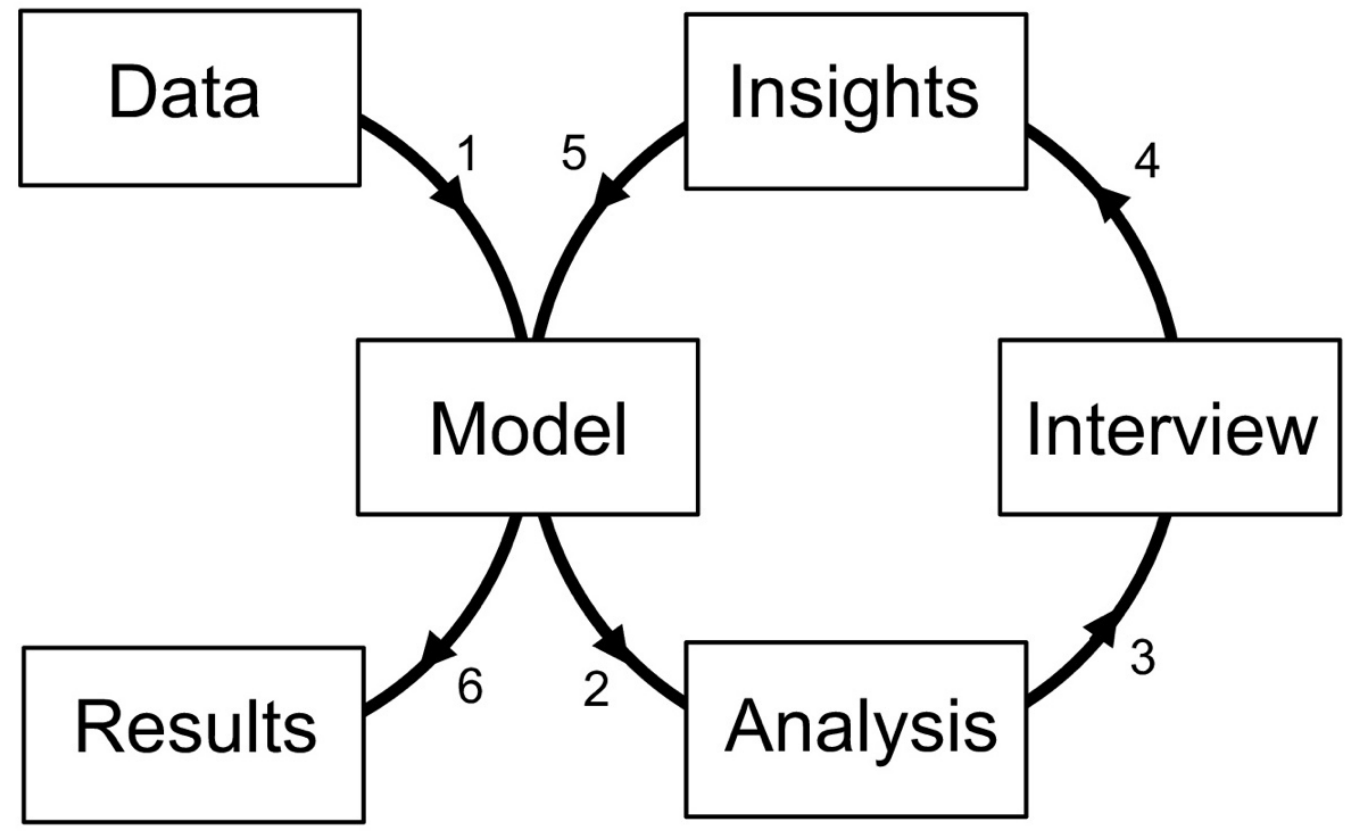

Figure 1: The overarching approach to the research depicting the information pathways between modelling processes and qualitative interview insights. 
In Cycle 2 - 'Data': remains the same. 'Analysis': took the results from Cycle 1 and integrated them into the interview materials. 'Interview': a semi-structured interview with adult householders was used to explore each household's understanding of energy reduction and their willingness to apply the selected reduction measures.

'Insights': the data from these interviews was then parameterised for implementation in the model. The 'Model': was re-run to yield a second set of reduction estimates tempered by the preferences of the householder. 'Results': a second set of results which account for each household's willingness to apply reductions. The results were then used to answer the following question: how does the willingness of the householder to apply changes in the home influence the expected energy demand reduction?

\section{Data and modelling approach}

Monitoring data was used to inform the model of each household: the dataset together with a full description of the measurement devices and calibration details can be freely downloaded from (Buswell, Webb, Cosar-Jorda, Marini, Brownlee, Thomson, Yang and Kalawsky, 2018). An overview of the method is provided here.

The hot water and gas consumption was monitored every second. The hot water data included hot water volume flow rate and water inlet and flow temperatures. The gas consumption was used for space-heating and hot water production and was measured using a bespoke device, details in (Buswell, 2013). Room air temperature was monitored every two minutes and current transducers were used to monitor power consumption every minute. Solar radiation, outdoor air temperature and wind speed data was collected from a local MIDAS weather station, about four miles from the households. 
Each household was modelled based on a single zone, steady-state heat-balance model of the building, evaluated daily using mean and aggregated variables over a 12-month period in 2013. The method is based on the following correlation,

$$
Q v=Q_{g}+Q_{e}+Q_{s}+Q_{p}+Q_{f}
$$

where the heat input to the space is from the heating system, ' $\mathrm{g}_{\mathrm{g}}$ ', and the heat produced by the appliances, 'Qe', both derived from monitoring data. The occupants body heat, ' $\mathrm{Q}_{\mathrm{p}}$ ', is based on occupancy and estimated heat gain (CIBSE, 2005). The solar gains, 'Qs', are calculated based on the BREDEM model procedures and the heat loss from the fabric, 'Q $\mathrm{f}_{\mathrm{f}}$, was estimated by using standard U-values for materials determined through an inspection of the building. The residual energy in the heat balance is attributed to heat flow in and out of the building via the ventilation and infiltration, ' $\mathrm{Q}_{\mathrm{v}}$ '.

The calculation used daily average outdoor air temperature values established from the weather station and the daily mean, bulk-average indoor air temperature, derived from a number of measurements in each home.

The energy balance is calculated for each day in the analysis and the residual attributed to heat loss through the air flow. Once complete, all variables in Equation 1, or the driving data, can then be used to model the effect of the reduction measures models. The model then used to estimate the resultant energy consumption $\left(\mathrm{Q}_{\mathrm{g}}\right.$ and $\left.\mathrm{Q}_{\mathrm{e}}\right)$, giving the values to compare from the base case. Further details of the approach are presented in an earlier publication (Cosar-Jorda, Buswell and Mitchell, 2018).

\section{Modelling the reduction measures}

16 reduction measures were identified via a comprehensive literature review and included well-known methods presented in previous research and government pathway 
reports (Oreszczyn, Hong, Ridley, Wilkinson and Group, 2006; DTI, 2007; Fawcett, Bottrill, Boardman and Lye, 2007; Mata, Kalagasidis and Johnsson, 2010; Moon and Han, 2011; Hall, Casey, Loveday and Gillott, 2013; Ben and Steemers, 2014; Martinaitis, Zavadskas, Motuzienè and Vilutienè, 2015).

A sub-set of measures were adopted, and these influenced the energy associated with building fabric, ventilation and infiltration, space-heating provision and the operational efficiency of technologies and appliances. The adaption of domestic practices that lower levels of service with respect to comfort and convenience were also considered. The degree to which each measure was implemented was based on literature and provided the basis for a 'limiting case' that enabled the evaluation of the 'theoretical limit' of energy demand reduction in each home. The measures explored in this work are summarised in Table 1.

Table 1: Energy reduction measures modelled in this work. Measures are categorised based on the change needed.

\begin{tabular}{llll}
\hline Reduction's category & Subcategory & Affects & Measure \\
\hline (Lifestyle) & Reduction & Service & Having just one fridge-freezer \\
& & No standby loads \\
& & No tumble drying \\
& & Heating when home \\
& & Room use heating \\
& & No heating over $15^{\circ} \mathrm{C}$ \\
& & Comfort & Heating to $17^{\circ} \mathrm{C}$ \\
& & & Minimum ventilation \\
& & Neplacement & New \\
& & appliances & \\
\hline (Technology) & Loft & Loft insulation
\end{tabular}




$\begin{array}{ll}\text { Walls } & \text { Fabric insulation } \\ \text { Floor } & \text { Floor insulation } \\ \text { Windows } & \text { Triple glazing } \\ \text { All } & \text { Sealing } \\ \text { building } & \\ \text { Heating } & \text { New boiler } \\ \text { system } & \end{array}$

Replacing lamps with LED units: the proportion of LED lamps in the house was estimated through self-reporting by householders; the aggregated lighting power consumption was the split using this proportion. The proportion that uses the old lamps is reduced by a factor of 5 (i.e. LED lamps use $20 \%$ of the power of conventional lamps);

Replacing appliances with more efficient units: a modest efficiency improvement of $10 \%$ was applied to all entertainment devices, laundry, cooking and cold appliances, based on a $1 \%$ annual improvement, and a standard domestic appliance lifespan of 10 years, (DECC, 2010; Weiss, Patel, Junginger and Blok, 2010). The monitored consumption was adjusted, and the aggregated daily values subtracted from the end use monitored electrical loads.

Switching off standby loads: the minutely data for appliances and devices were screened for standby power consumption when not in use; the standby loads were then aggregated and subtracted from the electric consumption.

Removing additional cold appliances so there remains just one fridge and one freezer or one fridge-freezer: the minutely consumption data for the additional appliance(s) were aggregated daily and subtracted. 
Only heating the house when at home: using the reported occupancy schedules from the household, the average internal air temperature data was filtered at the hourly sample level; outside these occupancy times, any temperatures were set to $16^{\circ} \mathrm{C}$ in the model, reflecting the minimum temperature to protect the building elements from condensation and frost; the ventilation and fabric heat losses were then recalculated with the new internal air temperature.

Restricting the heating to only those rooms that are occupied when the house is occupied: the assumption was that there will be an hour in the morning and six hours in the evening/night when the whole house is heated and then only one specified room heated according to use (working from home for example). A schedule is determined for each house and used to specify the heated and unheated temperatures at the hourly sample level. 'Unused' spaces, and the whole house at night are maintained to $16^{\circ} \mathrm{C}$, whereas 'used' spaces are maintained at the current temperatures; the new ventilation and fabric heat losses are calculated modelling two spaces for each scheduled time, the heated and unheated space.

Ensuring there is no space-heating unless the external air temperature is below $15^{\circ} \mathrm{C}$ : this is implemented by subtracting the gas consumption from days when the mean outdoor air temperature is $15^{\circ} \mathrm{C}$ or above.

Using $17^{\circ} \mathrm{C}$ as the internal air temperature set point temperature: the hourly mean temperature data was filtered and set to a maximum of $17^{\circ} \mathrm{C}$; these were then used to recalculate the daily average internal air temperatures.

Increasing the insulation of the building envelope: the floors, walls, roof, windows and doors were treated separately and are brought up to current building regulations as they apply to existing buildings $(0.15,0.19,0.13,1.4,1.0 \mathrm{Wm}-2 \mathrm{~K}-1$ respectively) (HM Government, 2010). 
Replacing the boiler with a more efficient unit: the improvement of a 95\% efficient boiler over the Seasonal Efficiency of Domestic Boilers in the UK (SEDBUK), rating for the installed unit was applied (HHG, 2018).

Sealing gaps and cracks in the fabric to minimise infiltration: the BREDEM method was used to estimate the reduction in ACR; the infiltration rate is estimated for each house based on house dependent parameters; the minimum ventilation rate achieved in testing from real retrofitting applied to homes was then used to model the new, post-sealed condition.

Minimising ventilation: the ventilation rate was set to the minimum required for physiological needs, about $0.5 \mathrm{~h}-1$ for a typical size UK home (ODPM, 2010).

\section{Analysis}

The measures were classified into three categories, 'Reduction', 'Replacement' and 'Retrofit'. Reduction represented those measures that require the householder to be willing to choose a lower level of either service or comfort. These measures potentially cost nothing to implement but needed the householder to change their domestic practices and routines. Replacement and Retrofit are differentiated as both require an investment, but the former is relatively straight forward to implement, whereas the latter is often highly disruptive (Zadeh, Hunt and Rogers, 2014).

The analysis was presented in two ways to each household. The first was in the context of published UK 2050 reduction targets. These were calculated based on figures published by the UK Government and the Energy Savings Trust (The Technology Strategy Board, 2009; DECC, 2010) which considered the anticipated number of expected dwellings in England in 2050 and the energy consumption per square meter that would meet the expected carbon emissions target based on future energy scenarios. 
This is a hypothetical figure that varies with the energy production mix and the range of carbon emissions from other sectors. If the future energy supply is de-carbonised, the demand requirement will be less critical. The energy demand target from the DECC higher nuclear scenario (Nuc) was $190 \mathrm{~kW} \mathrm{h/m2/year;} \mathrm{the} \mathrm{carbon} \mathrm{capture} \mathrm{and} \mathrm{storage}$ (CCS) scenario was $188 \mathrm{~kW} \mathrm{h/m2/yea} \mathrm{and} \mathrm{the} \mathrm{renewable} \mathrm{scenario} \mathrm{(Ren)} \mathrm{target,} \mathrm{was} 104$ $\mathrm{kW} \mathrm{h} / \mathrm{m} 2 /$ year. The target 2050 figure published by the Energy Saving Trust for a standard three-bedroom semi-detached property was adopted for this research. This occupied the middle ground of $115 \mathrm{~kW} \mathrm{~h} / \mathrm{m} 2 /$ year and $17 \mathrm{~kg} \mathrm{CO} 2 / \mathrm{m} 2 /$ year, based on achieving an $80 \%$ reduction in $\mathrm{CO}_{2}$, relative to 1990 levels (The Technology Strategy Board, 2013).

The second presentation was a comparison between the impact of 'lifestyle' measures compared to those measures that require an investment, which we call the 'Reduction Effort Balance' (REB). To quantify the reductions associated with each part of the REB, three reduction models were created: one which quantified the total annual energy consumption after applying replacement and retrofit measures; and a second from applying reduction measures which require the household to accept lower levels of service. The modelling results from applying each measure in isolation were also presented to householders.

\section{Interviews}

The semi-structured interviews with adult householders took place in participant homes to help their recollection of daily routines (Kujala, 2003). Each interview took two to three hours and was designed to engage participants with their personalised energy consumption information and explore their willingness to apply the proposed measures. A set of pie and bar charts were used to present households with their monitoring data, the energy reduction potential that each measure entailed and the estimated 2050 
reduction targets. The questions asked during the interviews and the graphs presented to householders are available in the Appendix.

Willingness to adopt the measures proposed was evaluated through the interview leading to a value on a six point scale being identified for each household for each reduction measure as presented in Table 2 .

Table 2: Model assumptions based on participants willingness.

\begin{tabular}{|l|l|l|}
\hline $\mathrm{N}$ & Participants willingness & Assumption in the model \\
\hline 1 & Willing to apply a measure & Assumptions as previously modelled \\
\hline 2 & Willing to apply a measure if a & Condition evaluation: it is applied if the \\
& condition is met & intervention \\
\hline 3 & Not willing to apply a measure & The model is corrected to disregard the measure \\
\hline 4 & Willing to partially apply a & Reduction assumptions customized in line with \\
& measure & participants willingness \\
\hline 5 & Already partially applying a & Measure disregarded \\
\hline 6 & Measure already applied & Measure disregarded \\
\hline
\end{tabular}

\section{Revisions to the model and model parameters}

The outcome of the interviews led to one of three revisions being made to how potential reductions were modelled: either the householders were willing to apply a measure or not, in which case it was or was not included in the Cycle 2 analysis; or the model 
parameters were adjusted to reflect where householders would be willing to accept a modified version of the measure. For example, if a householder was willing to apply a minimum indoor air temperature of $19^{\circ} \mathrm{C}$ but not $17^{\circ} \mathrm{C}$, the $17^{\circ} \mathrm{C}$ value was replaced with $19^{\circ} \mathrm{C}$ in the reduction model. Once all the reduction models were adjusted, the analysis was re-run to yield the energy reduction that would be achieved after considering only those measures which householders were willing to apply.

\section{The sample}

The sample comprised of six owner-occupied dwellings in the UK East Midlands. Table 3 provides details. 'Weekdays in' indicates the number of days when the house was typically occupied all day by at least one person due to either part time working, working from home, retirement, unemployment or full-time housekeeping. The occupancy profiles were established from initial interviews at the start of the project and updated regularly based on data collected over the course of the project, including when the households were visited to ensure that the monitoring equipment was functioning appropriately. 'Indoor temperature' is defined here as the daily mean bulk average indoor air temperature, which was calculated based on measured room temperatures. The building characteristics were typical of their respective years of construction. Insulation ranged from none (solid wall) in $\mathrm{H} 30$ and $\mathrm{H} 39$ to insulated cavity walls with and without loft insulation. Glazing also varied from a mix of basic single-glazed windows with timber frames to PVC framed double-glazed windows. The ground floor in all but one household was solid concrete, H05 was the exception with a suspended timber floor. 
Table 3: Key parameters for home energy consumption within the sample. 'D' and 'SD' denotes detached and semi-detached properties; 'IC', 'SW' denotes insulated cavity and solid wall; ' $\mathrm{D}$ ' and ' $\mathrm{S}$ ' double and single; and all houses have 2 floors

\begin{tabular}{|c|c|c|c|c|c|c|}
\hline House code & H05 & H10 & H30 & H37 & H39 & H46 \\
\hline Construction year & 1940 & 1980 & 1950 & 1970 & 1950 & 1990 \\
\hline House type & SD & $\mathrm{D}$ & $\mathrm{D}$ & $\mathrm{D}$ & $\mathrm{D}$ & SD \\
\hline Wall & IC & IC & SW & IC & SW & IC \\
\hline Glazing & $\mathrm{D}$ & $\mathrm{D}$ & $\mathrm{S}$ & $\mathrm{D}$ & $\mathrm{D}$ & $\mathrm{D}$ \\
\hline Boiler $(s)$ & $87 \%$ & $90 \%$ & $90 \%$ & $90 \%$ & $78 \%$ & $91 \%$ \\
\hline Cold appliances & 2 & 2 & 2 & 2 & 2 & 1 \\
\hline Efficient lighting & $50 \%$ & $25 \%$ & $75 \%$ & $25 \%$ & $50 \%$ & $25 \%$ \\
\hline Occupants & 3 & 4 & 2 & 4 & 4 & 6 \\
\hline Weekdays in & 1 & 5 & 5 & 5 & 1 & 5 \\
\hline Window opening (hrs/win) & 1 to 8 & $<3$ & 1 to 5 & 1 to 5 & $<3$ & 1 to 5 \\
\hline Openings monitored & 8 & 6 & 11 & 10 & 5 & 10 \\
\hline Indoor temperature & 18.0 & 19.0 & 17.8 & 18.7 & 17.5 & 21.2 \\
\hline
\end{tabular}

All houses had two floors and floor areas ranged from $100 \mathrm{~m}^{2}$ in $\mathrm{H} 30$ and $\mathrm{H} 39$ to $170 \mathrm{~m}^{2}$ in $\mathrm{H} 10$. Hot water and central space heating were supplied by combination boilers with a range of efficiencies between $79 \%$ and $91 \%$, and there was no space cooling system in place. Showers in households were provided with hot water from the main boiler and/or from electric showers (H37 and H39). 
The sample included a single parent family home with one child (H30); a multigeneration family home with four children, parents and grandmother (H46); three houses with four family members (H10, H37 and H39) and one house with three (H05). The age of the adults ranged from one young couple in their thirties (H46) to one mature couple in their late fifties (H05). The rest of the sample were within their late forties and early fifties. All the families were high and middle-income families with a variety of education levels from basic to post-graduate.

\section{Results}

The results are presented in four stages. The first explores the modelled impact of the energy reduction measures described above to establish their list ranking and the variability between households; the second investigates the energy reduction that can be achieved by each category in the REB; the third shows the capability of each house to meet the estimated 2050 reduction targets after modelling the effect of the willingness of each household to adopt energy reduction measures; and, finally the insights from the interviews on the challenges that householders face when trying to apply the suggested options are presented.

\section{Ranking the impact of measures (Cycle 1)}

The results from modelling each measure in isolation were ranked based on the average energy reduction achieved throughout the sample, see Table 4. Wall insulation ranked first on average, and minimising ventilation, fifth. The modelled impact of wall insulation was particularly high in two houses, H30 (30\% reduction) and H39 (64\% reduction), which were both detached properties with solid wall construction. Similar figures to those from H39 were found by (Banfill, S A Simpson, Gillott and White, 2011 ), suggesting that a $60 \%$ to $71 \%$ potential reduction was possible by applying 
retrofit measures to a solid wall house. The reduction in H30 was lower than expected, but this might be partly offset by the larger impact of ventilation, tempering the impact of the insulation.

Table 4: Ranking of the potential reduction by implementing each measure in isolation to each house. Energy reduction over 2013 in MWh/year and as a percentage (in parenthesis).

\begin{tabular}{clcccccc}
\hline Rank & \multicolumn{1}{c}{ Reductions } & H05 & H10 & H30 & H37 & H39 & H46 \\
\hline 1. & Fabric insulation & $2.7(10 \%)$ & $4.4(17 \%)$ & $9.8(35 \%)$ & $3.3(13 \%)$ & $14.8(62 \%)$ & $2.2(8 \%)$ \\
2. & Triple glazing & $2.4(9 \%)$ & $5.7(22 \%)$ & $5.9(21 \%)$ & $4.3(17 \%)$ & $3.4(14 \%)$ & $5.6(20 \%)$ \\
3. & Heating to $17{ }^{\circ} \mathrm{C}$ & $4.8(18 \%)$ & $4.9(19 \%)$ & $3.9(14 \%)$ & $4.5(18 \%)$ & $2.2(9 \%)$ & $7.0(25 \%)$ \\
4. & Room use heating & $4.3(16 \%)$ & $4.9(19 \%)$ & $4.8(17 \%)$ & $4.3(17 \%)$ & $1.7(7 \%)$ & $5.6(20 \%)$ \\
5. & Minimum ventilation & $8.4(32 \%)$ & $0.2(1 \%)$ & $4.7(17 \%)$ & $4.2(17 \%)$ & $1.2(5 \%)$ & $2.6(9 \%)$ \\
6. & New boiler & $1.9(7 \%)$ & $1.0(4 \%)$ & $1.7(6 \%)$ & $1.3(5 \%)$ & $3.6(15 \%)$ & $0.8(3 \%)$ \\
7. & Floor insulation & $2.9(11 \%)$ & $1.5(6 \%)$ & $0.8(3 \%)$ & $1.3(5 \%)$ & $1.0(4 \%)$ & $1.7(6 \%)$ \\
8. & Sealing & $1.1(4 \%)$ & $0.8(3 \%)$ & $0.6(2 \%)$ & $1.5(6 \%)$ & $0.7(3 \%)$ & $1.1(4 \%)$ \\
9. & New appliances & $0.5(2 \%)$ & $0.8(3 \%)$ & $0.3(1 \%)$ & $0.5(2 \%)$ & $0.5(2 \%)$ & $0.6(2 \%)$ \\
10. & Loft insulation & $0.0(0 \%)$ & $0.0(0 \%)$ & $2.3(8 \%)$ & $1.0(4 \%)$ & $0.2(1 \%)$ & $1.4(5 \%)$ \\
11. & No heating over $15{ }^{\circ} \mathrm{C}$ & $1.1(4 \%)$ & $0.5(2 \%)$ & $0.6(2 \%)$ & $0.5(2 \%)$ & $0.2(1 \%)$ & $0.6(2 \%)$ \\
12. & Heating when home & $0.3(1 \%)$ & $0.0(0 \%)$ & $0.0(0 \%)$ & $1.3(5 \%)$ & $0.2(1 \%)$ & $0.0(0 \%)$ \\
13. & No tumble drying & $0.0(0 \%)$ & $0.3(1 \%)$ & $0.3(1 \%)$ & $0.0(0 \%)$ & $0.0(0 \%)$ & $2.0(7 \%)$ \\
14. & One fridge-freezer & $0.0(0 \%)$ & $0.5(2 \%)$ & $0.0(0 \%)$ & $0.3(1 \%)$ & $0.2(1 \%)$ & $0.0(0 \%)$ \\
$15 . \quad$ Replace bulbs & $0.0(0 \%)$ & $0.0(0 \%)$ & $0.3(1 \%)$ & $0.0(0 \%)$ & $0.2(1 \%)$ & $0.0(0 \%)$ \\
16. & No standby loads & $0.0(0 \%)$ & $0.0(0 \%)$ & $0.0(0 \%)$ & $0.0(0 \%)$ & $0.0(0 \%)$ & $0.0(0 \%)$ \\
\hline
\end{tabular}

The replacement of windows with triple glazing could reduce energy consumption from $9 \%$ to up to $22 \%$, similar to reducing the indoor temperature set point to $17^{\circ} \mathrm{C}$. The maximum reduction would occur in $\mathrm{H} 46$ as the daily average indoor air 
temperature was over $21^{\circ} \mathrm{C}$ during the heating season, the highest from the sample. $\mathrm{H} 05$, $\mathrm{H} 10$ and $\mathrm{H} 37$, had a temperature range between $18^{\circ} \mathrm{C}$ and $19^{\circ} \mathrm{C}$. In $\mathrm{H} 30$, the potential reduction would be $14 \%$, as their current average temperature was just over $17^{\circ} \mathrm{C}$, very similar to H39.

The impact of heating only the rooms that are occupied was found to be as high as $20 \%$ in $\mathrm{H} 46$ and $\mathrm{H} 10$ and as low as $7 \%$ in $\mathrm{H} 39$; being between $14 \%$ and $16 \%$ in the other homes. The higher reductions correlate with partial weekday occupancy, in close agreement with the results of others (Meyers, Williams and Matthews, 2010; Beizaee, Allinson, Lomas, Foda and Loveday, 2015).

Switching off the heating when the temperature outside is above $15^{\circ} \mathrm{C}$ would reduce energy consumption from $1 \%$ in $\mathrm{H} 39$, to $4 \%$ in $\mathrm{H} 05$, suggesting that within the sample the heating was switched off relatively early in the year and not switched on until later in the colder seasons.

Switching off the heating when the house is unoccupied was not found to be a significant reduction strategy in the sample, as houses were mostly occupied during the week. No reductions would be possible in $\mathrm{H} 10, \mathrm{H} 30$, and $\mathrm{H} 46$, unless there was a change to their current working patterns and occupancy profiles, whereas a $5 \%$ reduction would be possible in $\mathrm{H} 05$ and $\mathrm{H} 37$.

Whereas boiler replacement would yield a $15 \%$ reduction in $\mathrm{H} 39$, which had the most inefficient boiler in the sample, only $3 \%$ reduction would be possible in H46. The addition of floor insulation would reduce energy consumption by $11 \%$ in $\mathrm{H} 05$, which had a suspended timber floor, and the impact of loft insulation was found to be high in H30, which did not have any insulation, however all other houses had already added insulation, so modelled reductions were marginal. 
The use of the tumble dryer within the sample was not significant except for H46, who used the appliance extensively, over four times that of the national average (Owen and Foreman, 2012), with a modelled potential 7\% reduction. All houses except H46 and H37 had more than one refrigerator with potential savings resulting from dropping to one between $1 \%$ and $2 \%$ for the sample.

The modelled increase of the building fabric air-tightness resulted in reductions ranging from $4 \%$ to $7 \%$, very similar to previous results (Ren and Chen, 2015). The low variability in the results can be attributed to the simplicity of the calculation approach, which applies assumptions to the building characteristics to determine the infiltration rate (Henderson and Hart, 2012). Results however suggest that sealing gaps and cracks in the fabric would not be effective for those households that desire high ventilation rates.

Decrease of ventilation to the minimum stated in the UK Building Regulations (ODPM, 2010), could reduce energy consumption by up to $32 \%$ in $\mathrm{H} 05$, which could be attributed to the amount of window operation (Cosar-Jorda, Buswell and Mitchell, 2018). In H37, where windows were thoughtfully operated, a 17\% reduction might still be possible. $\mathrm{H} 30$ and $\mathrm{H} 46$, could reduce their consumption by $9 \%$ but $\mathrm{H} 10$ might benefit from only a $1 \%$ reduction as windows were rarely opened and the ventilation reductions in effect tackle infiltration. Sealing gaps and cracks in the fabric might yield a higher 3\% reduction for this dwelling.

\section{The Reduction Effort Balance}

Figure 2 depicts the results from applying the REB reduction models, showing the balance of Reduction, Replacement and Retrofit measures in each house that contributed to each total reduction. The minor impact of replacing appliances for more efficient units in all homes was evident: the highest reduction being 5\% in $\mathrm{H} 46$ and as 
low as $1 \%$ in $\mathrm{H} 05, \mathrm{H} 10, \mathrm{H} 30$ and $\mathrm{H} 39$.

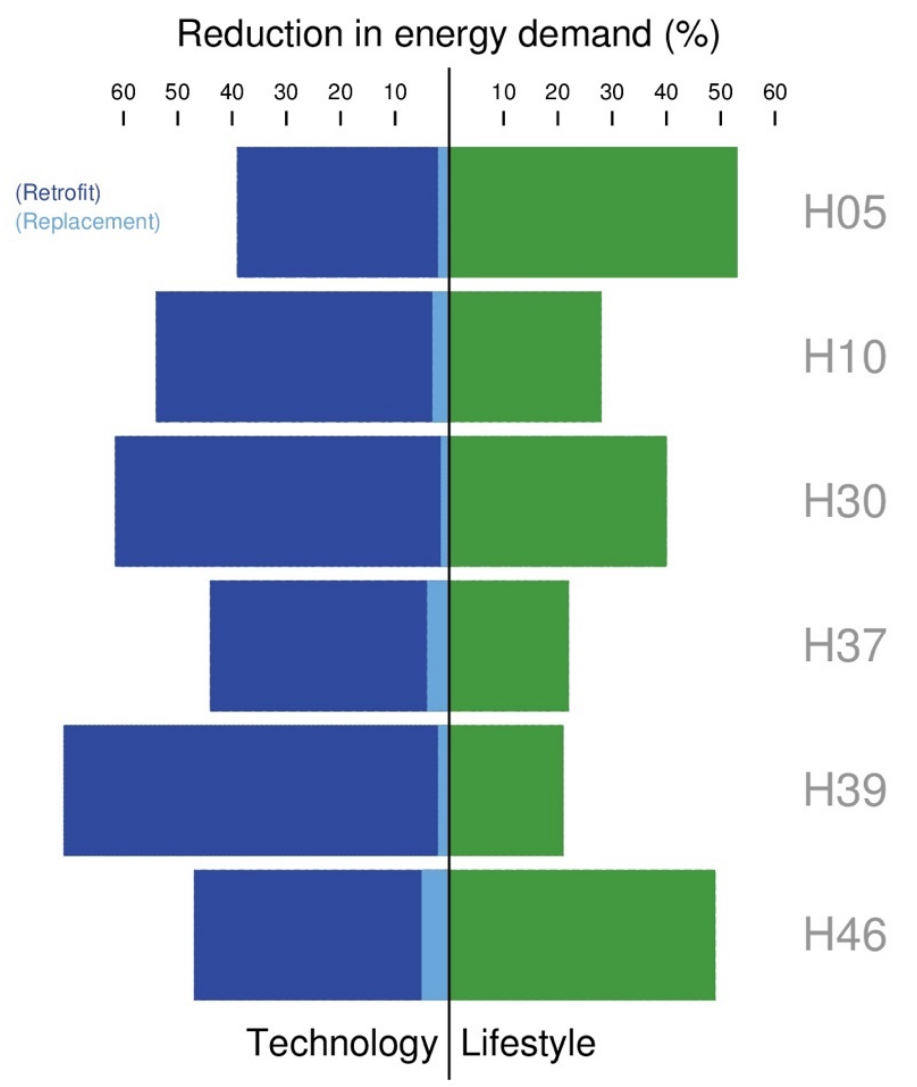

Figure 2: The Reduction Effort Balance for each household. Replacement and Retrofit options are combined into the technology categories on the left which require investment and the lifestyle driven reductions on the right, being those that may be achieved with little or no cost but do require a reduction of comfort and service.

The impact of Reduction (lifestyle) measures was particularly high in H05, where they could potentially achieve up to 53\% reduction; H05 and H46 were the only households where the potential reduction from application of lifestyle measures was higher than for retrofit measures. In H05 the main reason for the high potential impact of lifestyle measures, was their ventilation practices, leading to significant heat loss during winter months (Cosar-Jorda, Buswell and Mitchell, 2018). In H46, the magnitude of their energy consumption was determined by the number of people that 
occupied the home (six), the high average indoor air temperature and the constant space heating due to occupancy during the week by an elderly relative.

Retrofit options are key in $\mathrm{H} 30$ and $\mathrm{H} 39$, leading to $60 \%$ and $69 \%$ energy reduction. In $\mathrm{H} 39$, the high potential was mainly due to the difference in transmissivity of the solid brick walls to the current Building Regulation standards. However, in H30, it was the result of a combination of unfavourable building characteristics, i.e. no loft insulation, single glazing, and solid walls. Overall, lifestyle measures could potentially achieve, at least, half of the reductions of those from applying retrofit measures, except for H39, which was attributed to the average indoor temperature, low occupancy during the week, and their ventilation practices. Results suggest therefore that the pathways to achieving domestic energy demand reduction varies between households as a consequence of the building type, its systems and the way in which preferences and routines differ.

\section{Impact on reduction levels of household's willingness to adopt (Cycle 2)}

The willingness to adopt the proposed measures for each household is summarised in Table 5. A simple traffic light scheme is used to illustrate the degree to which households were willing to apply a measure. Green and red indicate that the household was/was not willing to apply a measure respectively. Orange indicates a willingness to apply, but only partially. For retrofit and replacement measures this indicates a willingness to implement the measure to some aspects of their home but not others, for example to clad some walls but not others or to replace some lamps but not all lamps in the home. For lifestyle measures, orange indicates a willingness to accept some reduction in service but not to the extent suggested, for example, willingness to accept some reduction in the space heating set point but not to $17^{\circ} \mathrm{C}$ which was considered too 
cold in all but one home (H05).

Table 5: Energy reduction measures' acceptability. Green indicates the measure is acceptable; orange is partially acceptable; and red for unacceptable.

$\begin{array}{lllll}\text { Reductions (\%) } & \text { Ho5 } & \text { H10 } & \text { H3o } & \text { H37 } \\ \text { Minimum ventilation } & \text { H39 } \\ \text { Sealing } & \text { H46 } \\ \text { Appliances, lighting and boiler update } & \text { Heating to } 17^{\circ} \mathrm{C} \\ \text { Space heating tailored settings } & \text { No heating over } 15^{\circ} \mathrm{C} \\ \text { No tumble drying } & \\ \text { No standby loads } \\ \text { One fridge-freezer }\end{array}$

The insights generated by the interviews were translated to a quantitative measure through the model and the results plotted in Figure 3. The dark blue bar gives the annual energy consumption for the household in 2013, the light green bar is the modelled consumption after all measures detailed in Table 1 have been applied at the limiting cases, and the dark green bar indicates the modelled consumption including only those measures which householders were willing to apply. The estimated household 2050 target for each home (based on the floor area) are noted by a red line. The effect of the willingness (or lack thereof) to adopt measures was highest in H05, where less than half of the potential reductions could be achieved. The other households were more willing to adopt reduction measures, although this varied between homes and all presented some degree of resistance to the measures. 


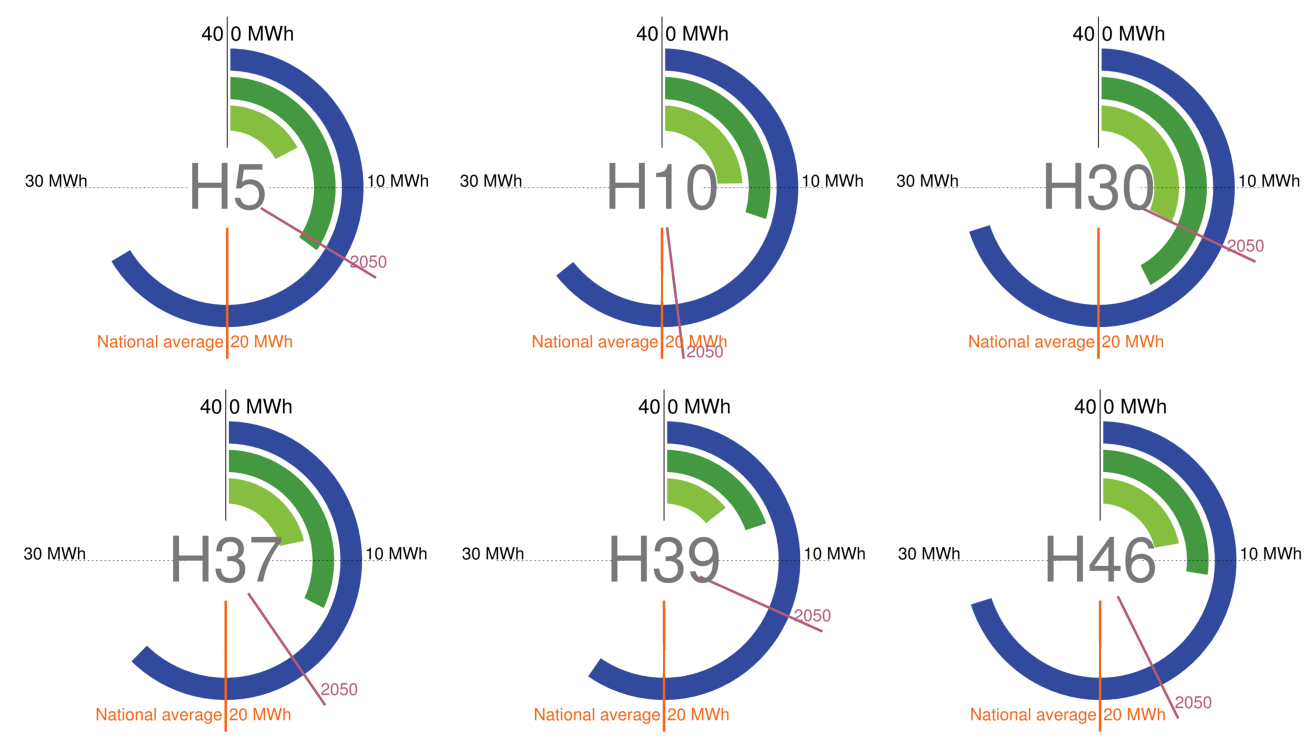

Figure 3: The impact of demand reduction measures. Total annual energy consumption (2013) is shown by the dark blue bar. The light green bar shows the resultant consumption after applying all measures to create a 'theoretical limit' case. The dark green bar represents a more realistic potential demand reduction after accounting for the willingness of householders to adopt the measures. The estimated 2050 targets tailored for each home is shown by a red line.

Considering the maximum reductions possible when applying those measures that householders were willing to adopt, the results would indicate that in four out of the six households the estimated 2050 targets could be achieved comfortably. In practice, however, this would require families to live with a considerable departure from their current norms, i.e. living in an ambient temperature no higher than $17^{\circ} \mathrm{C}$, using minimum ventilation and only partially heating the house. Hence, although we tested the 'willingness' to apply measures, actual reductions might be expected to be less in practice (Herring and Roy, 2007). Our results therefore reflect a 'best case scenario'. 


\section{Interview insights}

\section{Building fabric}

To reach the current thermal transmissivities in the UK building regulations, all homes in the sample would need to undergo the treatment process for solid wall construction, even pre-1990's cavity wall buildings, which is expensive and disruptive. Similar concerns to those found by (Karvonen, 2013) were raised: '... we could probably do more if we insulated the house more, but at the moment the cost of that is prohibitive because we've got a solid wall house'. (H30), and '...it would be a big disruption.' (H39); '... The problem for me is that you're then moving away from a brick facade to a rendered facade.' (H37). Interest in insulating the ground floor was generally low for similar reasons. Replacing windows was an option that would be considered except for the high cost, with households commenting that financial help from a government incentive scheme could make such changes more attractive and feasible in the future.

\section{Space heating control}

Half the houses were occupied most of the time (H10, H30 and H46). 'Switching off the heating when no one is at home' was already applied to a certain degree through manual intervention utilising typical Thermostatic Radiator Valves (TRVs), thermostats and programmable controllers. Heating occupied rooms instead of the whole house was also manually applied in some houses (H05, H09, H10 and H39). All householders expressed their willingness to heat only occupied rooms but found it difficult to implement in practice.

Householders were generally not willing to reduce the indoor temperature to $17^{\circ} \mathrm{C}$. Strong resistance to this was voiced in $\mathrm{H} 46$ which housed an extended family including a grandparent and a baby. H05, H09, H30 and H37 considered setting lower 
indoor temperatures than those enjoyed currently, but only $\mathrm{H} 05$ was willing to reduce the indoor temperature to $17^{\circ} \mathrm{C}$. $\mathrm{H} 30, \mathrm{H} 37$ and $\mathrm{H} 39$ were comfortable with a set point temperature of $18^{\circ} \mathrm{C}$ and $\mathrm{H} 10$ were happy to reduce their current temperature by $1^{\circ} \mathrm{C}:$ '... I am not going to worry about the energy consumption at the cost of comfort...but if it is at $19,20\left[{ }^{\circ} \mathrm{C}\right]$ and the boys need to put a jumper on, then that is fine.'

\section{Ventilation}

The impact of ventilation varied significantly within the sample, evidenced in the model analysis and corroborated in the interviews. The two extreme cases were H05, who reported that most windows were opened for many hours per day and H10 who reported that windows were only occasionally opened to deal with steam in the bathroom. Most participants considered fresh air was important to achieve comfortable conditions in the home, indispensable for a healthy environment, essential to keep awake, important to remove ambient odour after sleeping or cooking, or to avoid condensation and damp. In $\mathrm{H} 05$, ventilation was closely related to their daily routines around a pet '... the dog comes in and out as he pleases, we leave the door open for him which is maybe not something we should do...'.

Limiting window operation or installing of a Mechanical Ventilation (MV) system to minimise energy loss was an acceptable option only for H39 and H46. All understood that unsealed doors and windows were a source of heat loss and would be willing to improve air-tightness, although concerns over cost and disruption were raised.

\section{Appliances}

Householders who owned more than one fridge-freezer were not willing to reduce the number of cold-appliances (except for H30), because they were ingrained in everyday routines (Strengers, 2011). Moderating the use of the tumble drier was also found to be 
unattractive, not even in $\mathrm{H} 46$ where consumption was quite high. Tumble drier use was lower than the national average in the sample except for H46 and opportunities for reduction were therefore not seen by householders as significant. The replacement of appliances was mainly driven by end of life in the case of boilers and white goods, but in the case of entertainment and digital media was driven by obsolescence and function.

\section{Discussion}

To the best knowledge of the authors, this is the first time that the impact of the willingness to adopt energy demand reduction measures by householders on potential reduction has been quantified. The effect of any one reduction measure is influenced by the constraints imposed by the householders who need to be willing to adopt the measure and, in some instances, be willing to lower their service expectations. Interestingly, the potential from changing domestic practices can be as high as that from retrofit options and offers a reduction of at least $22 \%$ in each house in the sample. The insights gained from the approach suggest that the reasons why some households could achieve target levels and not others are embedded in domestic practices such as fulltime occupancy during the week and preferred temperature and ventilation routines. For houses where internal temperatures were not seen as negotiable, the most effective reduction measures tended to be improving insulation and sealing gaps and cracks to ensure minimum infiltration. For houses that are occupied for most of the week, optimised space-heating controls appear to be most relevant, as high occupancy during working days is recognised as a key factor driving space-heating energy consumption (Richardson, Thomson, Infield and Clifford, 2010). This suggests a role for smart heating controls to help minimise energy demand and mitigate likely reductions in comfort (Darby, 2010). Homes with solid wall construction were most likely to struggle to meet the estimated 2050 targets without investment. For such households, insulation 
should come first, then lifestyle changes related to the use of space-heating.

Replacement of appliances is a key moment to encourage the selection of the most efficient option, but also an opportunity to reconfigure established practices and reduce energy demand through establishing new patterns of interaction (Gram-Hanssen, 2011). We also found that acquiring a new appliance not always resulted in a replacement but in the maintaining of the old one, a second fridge/freezer being common, and that householders were resistant to relinquish the service this provided. Other challenging reductions in the sample homes were in relation to tumble dryer use, reducing standby loads and, perhaps more significantly changing ventilation practices. It was observed that ventilation patterns, which are key for energy consumption, were highly influenced by personal meaning and understanding, driving very extreme practices in some homes. The interview findings suggest that householders need more information regarding their ventilation practices and their impact on energy consumption. Although there are energy benefits from the application of mechanical ventilation systems (Banfill, Sophie A Simpson, Gillott and White, 2011), this work suggests that changing ventilation practices in existing homes will be challenging, particularly when a significant investment from the householder is required.

We found that the willingness to adopt retrofit options was influenced predominately by the level of investment needed and whether the measure would result in potential financial savings within a sensible payback time; confirming the need for local or national incentive schemes to make such measures cost effective. In terms of technology updates (e.g. appliances, boilers, radiators), this was predominately driven by break-downs or malfunction rather than a desire to upgrade.

Although the approach presented here quantifies the effect that reported willingness to change can have upon predicted energy reduction, this quantification is 
most likely limited by the difference between self-report at the time of the interview and the realities of everyday practice. However, this approach could be used as a tool to inform households about how their preferences impact on consumption, thus helping them decide the most appropriate measures for their particular home and lifestyle.

The insights presented here are limited by the sample size and characteristics, and a bigger sample is needed to drive policy discussions. However, owner-occupied dwellings make up $64 \%$ of the UK housing stock and have the highest energy reduction potential (Department for Communities and Local Government, 2016), particularly in university educated family households (Morton, Wilson and Anable, 2018).

The method can be implemented using measurements from monitoring devices and smart meters, making it flexible and scalable. Capturing the insights from householders is an invaluable part of the process, which was in this case achieved through interviews, but could be simplified using an online survey tool. Accounting for willingness to engage with reduction measures at a household level is likely to help mitigate the observed differences between estimated and achieved reductions (Belaïd, Bakaloglou and Roubaud, 2018), although further work should seek to quantify the difference between the impact from households' reported willingness to apply measures and actual changes applied.

\section{Conclusion}

The reduction of domestic energy demand is an important part of future supply, but reductions in owner-occupied dwellings can only be implemented by the householder, who needs to understand what approach leads to the most significant impact for their specific circumstances. This work has demonstrated the variability in the potential impact of a range of reduction measures across a number of notionally 'similar' homes and introduced an approach that combines simple modelling with monitoring data and 
interviews to enable tailored feedback in order to identify the most appropriate intervention methods for a specific household.

We found that when potential energy demand reduction measures are listed, they can be placed into one of two categories: technology, or lifestyle. The former requires investment and the latter the adopting of new routines and preferences that lower service expectations, some aspects of which might in the future be offset through the application of smart home technologies. This is useful in articulating where the householder should place their energy reduction effort: guiding them to achieve low effort energy demand reduction. The optimum balance of measures in households varies significantly and wall construction and ventilation practices play a key role in determining the most effective technology/lifestyle intervention.

The analysis found that achieving the estimated 2050 demand targets varied between households, with some easily achieving the necessary reductions and others finding it difficult even under the most stringent conditions.

The research has demonstrated the complexity of identifying the best pathways to demand reduction. The approach used here shows promise in helping to identify these pathways for individual households. Analysis over a larger sample would help build a clearer picture of how these issues might impact national demand reduction aspirations, and also confirm that significant reductions in demand are possible through better advice, education and normalisation of lower levels of service with respect to comfort and convenience.

\section{Acknowledgements}

This paper forms part of the work produced under the LEEDR: Low Effort Energy Demand Reduction Project based at Loughborough University, UK. The work was funded through the TEDDI call managed by the RCUK Digital Economy and Energy programmes (EPSRC Grant 
Number EP/I000267/1). The LEEDR project gratefully acknowledges the participation of the families in the study.

\section{References}

Abrahamse, W. and Steg, L. (2011) 'Factors related to household energy use and intention to reduce it: The role of psychological and socio-demographic variables', Human Ecology Review. JSTOR, pp. 30-40.

Banfill, P. F. G., Simpson, Sophie A, Gillott, M. C. and White, J. (2011) 'Mechanical ventilation and heat recovery for low carbon retrofitting in dwellings', in World Renewable Energy Congress-Sweden; 8-13 May; 2011; Linköping; Sweden, pp. 11021109.

Banfill, P. F. G., Simpson, S A, Gillott, M. C. and White, J. (2011) 'The potential for energy saving in existing solid wall dwellings through mechanical ventilation and heat recovery', European Council for an Energy Efficient Economy, summer study, pp. 6-31.

Baruah, P. J., Eyre, N., Qadrdan, M., Chaudry, M., Blainey, S., Hall, J. W., Jenkins, N. and Tran, M. (2014) 'Energy system impacts from heat and transport electrification', Proceedings of the Institution of Civil Engineers-Energy, 167(3), pp. 139-151.

Beizaee, A., Allinson, D., Lomas, K. J., Foda, E. and Loveday, D. L. (2015) 'Measuring the potential of zonal space heating controls to reduce energy use in UK homes: The case of un-furbished 1930s dwellings', Energy and Buildings. Elsevier, 92, pp. 29-44.

Belaïd, F., Bakaloglou, S. and Roubaud, D. (2018) 'Direct rebound effect of residential gas demand: Empirical evidence from France', Energy Policy, 115, pp. 23-31. doi: https://doi.org/10.1016/j.enpol.2017.12.040.

Ben, H. and Steemers, K. (2014) 'Energy retrofit and occupant behaviour in protected 
housing: A case study of the Brunswick Centre in London', Energy and Buildings.

Elsevier, 80, pp. 120-130.

Buswell, R., Webb, L., Cosar-Jorda, P., Marini, D., Brownlee, S., Thomson, M., Yang,

S.-H. and Kalawsky, R. (2018) 'LEEDR project home energy dataset'. doi:

10.17028/rd.lboro.6176450.v1.

CIBSE (2005) 'Guide $\{\mathrm{B}\}$ : Heating, ventilating, air conditioning and refrigeration', The Chartered Institution of Building Services Engineers, London.

Clegg, S. and Mancarella, P. (2018) 'Integrated electricity-heat-gas modelling and assessment, with applications to the Great Britain system. Part II: Transmission network analysis and low carbon technology and resilience case studies', Energy. Elsevier.

Committee on Climate Change (2015) '5th Carbon Budget'.

Cosar-Jorda, P. (2017) A Socio-technical evaluation of the impact of energy demand reduction measures in family homes.

Cosar-Jorda, P., Buswell, R. A. and Mitchell, V. A. (2018) 'Determining of the role of ventilation in residential energy demand reduction using a heat-balance approach', Building and Environment. Elsevier.

DECC (2010) '2050 Pathways Analysis'. Department of Energy and Climate Change London. Available at:

https://assets.publishing.service.gov.uk/government/uploads/system/uploads/attachment _data/file/42562/216-2050-pathways-analysis-report.pdf.

DECC (2017) 'Energy Consumption in the United Kingdom'. 
Department for Communities and Local Government (2012) English housing survey. Headline Report 2011-2012.

DTI, U. K. (2007) 'Meeting the energy challenge:A white paper on energy', Department for Trade and Industry, Cm7124.

ECCC (2016) 'Home Energy efficiency and demand reduction'. Available at: https://publications.parliament.uk/pa/cm201516/cmselect/cmenergy/552/552.pdf.

Energy Saving Trust (2015) Energy saving quick wins. Available at: https://www.energysavingtrust.org.uk/home-energy-efficiency/energy-saving-quickwins (Accessed: 26 March 2019).

European Commission (2017) 'Good practice in energy efficiency: For a sustainable, safer and more competitive Europe', Clean energy for all europeans, p. 50. doi: $10.1086 / 304912$.

Fawcett, T., Bottrill, C., Boardman, B. and Lye, G. (2007) 'Trialling personal carbon allowances. UKERC'.

Gram-Hanssen, K. (2011) 'Understanding change and continuity in residential energy consumption', Journal of Consumer Culture, 11(1), pp. 61-78.

Haines, V., Mitchell, V. and Mallaband, B. (2010) 'Using a practice-orientated approach to inform the design of energy efficiency measures for older homes'. ERSCPEMSU. Available at: https://dspace.lboro.ac.uk/dspace-jspui/handle/2134/9604 (Accessed: 12 April 2019).

Haines, V., Mitchell, V. and Mallaband, B. (2012) 'Merging a practice-orientated approach with an engineering-driven product development: a case study on home 
improvement', Journal of Design Research 14. Inderscience Publishers Ltd, 10(1-2), pp. 28-49.

Hall, M. R., Casey, S. P., Loveday, D. L. and Gillott, M. (2013) 'Analysis of UK domestic building retrofit scenarios based on the E.ON Retrofit Research House using energetic hygrothermics simulation â€“" Energy efficiency, indoor air quality, occupant comfort, and mould growth potential', Building and Environment, 70(0), pp. 48-59.

Henderson, J. and Hart, J. (2012) 'BREDEM 2012, A technical description of the BRE Domestic Energy Model’. Building Research Establishment, UK.

Herring, H. and Roy, R. (2007) 'Technological innovation, energy efficient design and the rebound effect', Technovation. Elsevier, 27(4), pp. 194-203.

HHG (2018) 'Home Heating Guide: boiler efficiency tables'. Available at: https://www.homeheatingguide.co.uk/efficiency-tables.

HM Government (2010) 'The Building Regulations 2010: Conservation of fuel and power in existing dwellings'.

Hong, S. H., Gilbertson, J., Oreszczyn, T., Green, G. and Ridley, I. (2009) ‘A field study of thermal comfort in low-income dwellings in England before and after energy efficient refurbishment', Building and Environment. Pergamon, 44(6), pp. 1228-1236. doi: 10.1016/J.BUILDENV.2008.09.003.

Karvonen, A. (2013) 'Towards systemic domestic retrofit: a social practices approach', Building Research \& Information. Taylor \& Francis, 41(5), pp. 563-574.

Kujala, S. (2003) 'User environment: a review of the benefits and challenges', Behaviour \& information technology, pp. 1-16. 
Love, J. and Cooper, A. C. (2015) 'From social and technical to socio-technical:

Designing integrated research on domestic energy use', Indoor and Built Environment, 24(7), pp. 986-998. doi: 10.1177/1420326X15601722.

Martinaitis, V., Zavadskas, E. K., Motuzienè, V. and Vilutienė, T. (2015) 'Importance of occupancy information when simulating energy demand of energy efficient house: A case study', Energy and Buildings, 101, pp. 64-75.

Mata, E., Kalagasidis, A. S. and Johnsson, F. (2010) 'Assessment of retrofit measures for reduced energy use in residential building stocks-Simplified costs calculation', in Proceedings of Sustainable Building Conference SB10mad. 28-30 April 2010, Madrid, Spain.

Meyers, R. J., Williams, E. D. and Matthews, H. S. (2010) 'Scoping the potential of monitoring and control technologies to reduce energy use in homes', Energy and Buildings. Elsevier, 42(5), pp. 563-569.

Moon, J. W. and Han, S.-H. (2011) 'Thermostat strategies impact on energy consumption in residential buildings', Energy and Buildings, 43(2-3), pp. 338-346. doi: 10.1016/j.enbuild.2010.09.024.

Morton, C., Wilson, C. and Anable, J. (2018) 'The diffusion of domestic energy efficiency policies: A spatial perspective', Energy Policy. Elsevier, 114, pp. 77-88.

Nejat, P., Jomehzadeh, F., Taheri, M. M., Gohari, M. and Majid, M. Z. A. (2015) ‘A global review of energy consumption, $\mathrm{CO} 2$ emissions and policy in the residential sector (with an overview of the top ten $\mathrm{CO} 2$ emitting countries)', Renewable and Sustainable Energy Reviews, 43, pp. 843-862. doi: https://doi.org/10.1016/j.rser.2014.11.066. 
ODPM (2010) 'The Building regulations 2006 \{(F): Ventilation, Approved document $\}$ '.

Oreszczyn, T., Hong, S. H., Ridley, I., Wilkinson, P. and Group, W. F. S. (2006)

'Determinants of winter indoor temperatures in low income households in England', Energy and Buildings, 38(3), pp. 245-252.

Owen, P. and Foreman, R. (2012) 'Powering the nation: Household electricity using habits revealed', Energy Saving Trust/DECC/DEFRA, London. Available at: http://www.energysavingtrust.org.uk/sites/default/files/reports/Poweringthenationreport CO332.pdf.

Pink, S., Mackley, K. L. and Morolcsanu, R. (2015) 'Hanging out at home: Laundry as a thread and texture of everyday life', International Journal of Cultural Studies. Sage Publications Sage UK: London, England, 18(2), pp. 209-224.

Ren, Z. and Chen, D. (2015) 'Estimation of air infiltration for Australian housing energy analysis', Journal of Building Physics. SAGE Publications Sage UK: London, England, 39(1), pp. 69-96.

Richardson, I., Thomson, M., Infield, D. and Clifford, C. (2010) 'Domestic electricity use: A high-resolution energy demand model', Energy and Buildings, 42(10), pp. 18781887.

S.Darby (2010) 'Smart metering: what potential for householder engagement?', Building Research and Information, 38(5), pp. 442-457.

Shove, E. (2003) 'Converging Conventions of Comfort, Cleanliness and Convenience', Journal of Consumer Policy, 26(4), pp. 395-418.

Shove, E. (2018) 'What is wrong with energy efficiency?', Building Research \& 
Information. Routledge, 46(7), pp. 779-789. doi: 10.1080/09613218.2017.1361746.

Strengers, Y. (2011) 'Negotiating everyday life: The role of energy and water consumption feedback', Journal of Consumer Culture, 11(3), pp. 319-338. doi: $10.1177 / 1469540511417994$.

Sunikka-Blank, M. and Galvin, R. (2012) 'Introducing the prebound effect: the gap between performance and actual energy consumption', Building Research \& Information. Routledge, 40(3), pp. 260-273. doi: 10.1080/09613218.2012.690952.

The Technology Strategy Board (2009) 'Evaluating the energy security implications of a carbon constrained U.S. economy'.

Vadodaria, K., Loveday, D. L., Haines, V., Mitchell, V., Mallaband, B. and Bayer, S. H. (2010) 'UK solid-wall dwellings-thermal comfort, energy efficiency refurbishment and the user perspective-some preliminary analysis from the CALEBRE project'.

Weiss, M., Patel, M. K., Junginger, M. and Blok, K. (2010) 'Analyzing price and efficiency dynamics of large appliances with the experience curve approach', Energy Policy. Elsevier, 38(2), pp. 770-783.

Zadeh, S. M., Hunt, D. V. L. and Rogers, C. D. F. (2014) 'Socio-technological influences on future water demands', Water, 6(7), pp. 1961-1984. 


\section{Appendix}

The following questions were used to explore householder motivation towards reducing energy demand and their current knowledge on why and how to achieve it. The 2050 energy demand figures specific to their household characteristics were presented to participants, as in Figure A.1, where the left bar shows their current consumption and the right bar the target level.

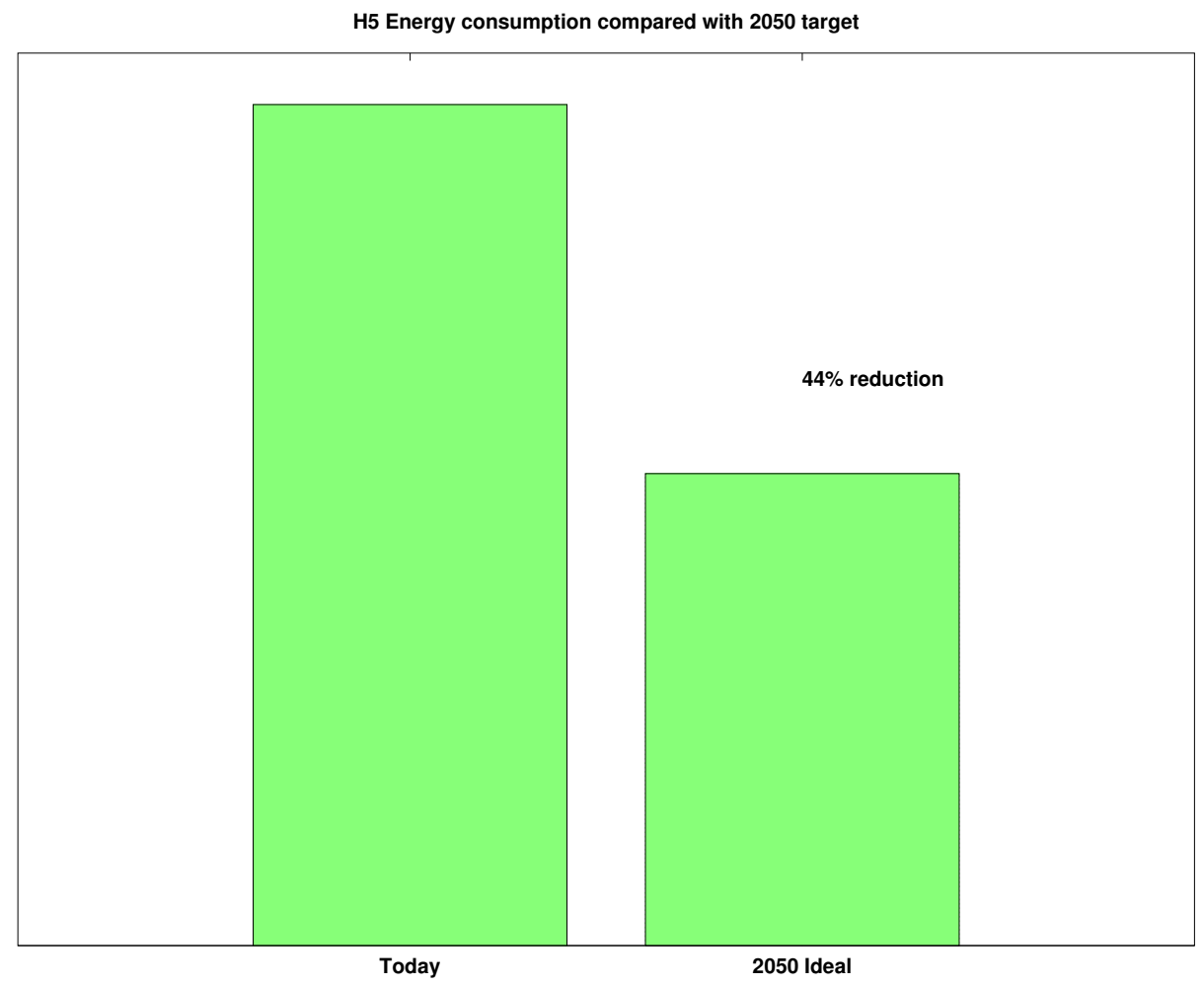

Figure A.1: The figure presented to households to inform them of their current consumption (left bar) and the energy demand reduction proportion needed to achieve their 2050 target (right hand).

- How realistic do you think it is to get to the presented 2050 target energy demand savings?

- Are those targets relevant for you? Why? 
- Is energy reduction relevant for you for any other reason?

- What can you do to save energy in the home?

- Can you rank the most important measures to reduce energy?

Householders were presented the energy reduction potential that each measure entails and the total energy reduction potential compared to 2050 target levels.

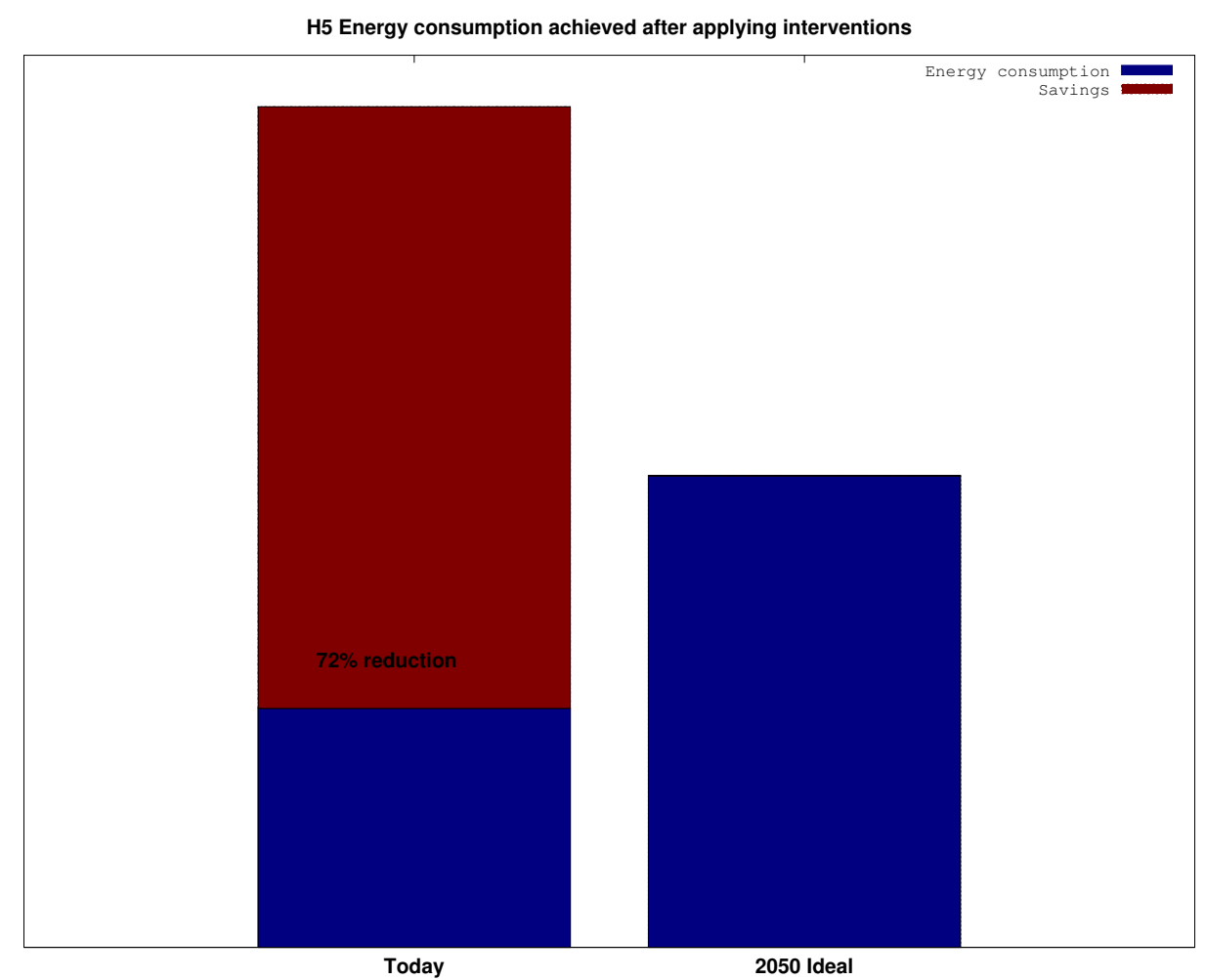

Figure A.2: The plot presented to households to explain the proportion of energy demand reduction modelled relative to their current consumption (left bar, red colour), and the resultant future demand (left bar, blue colour). The right-hand bar shows the energy demand reduction proportion needed to achieve their 2050 target.

Firstly, Figure A.2 was shown, where the left bar shows their current consumption (red + blue) and the potential reduction (red), the right bar shows the 2050 target. Looking at the graph it was asked: 
- Do you think it is feasible to get to the reduction modelled? If so why/why not?

Then, Figure A.3 was presented to show all the modelled reductions and their potential reduction in isolation. Looking at the figures, we compared the options modelled and their potential reduction with their initial ideas and expectations.

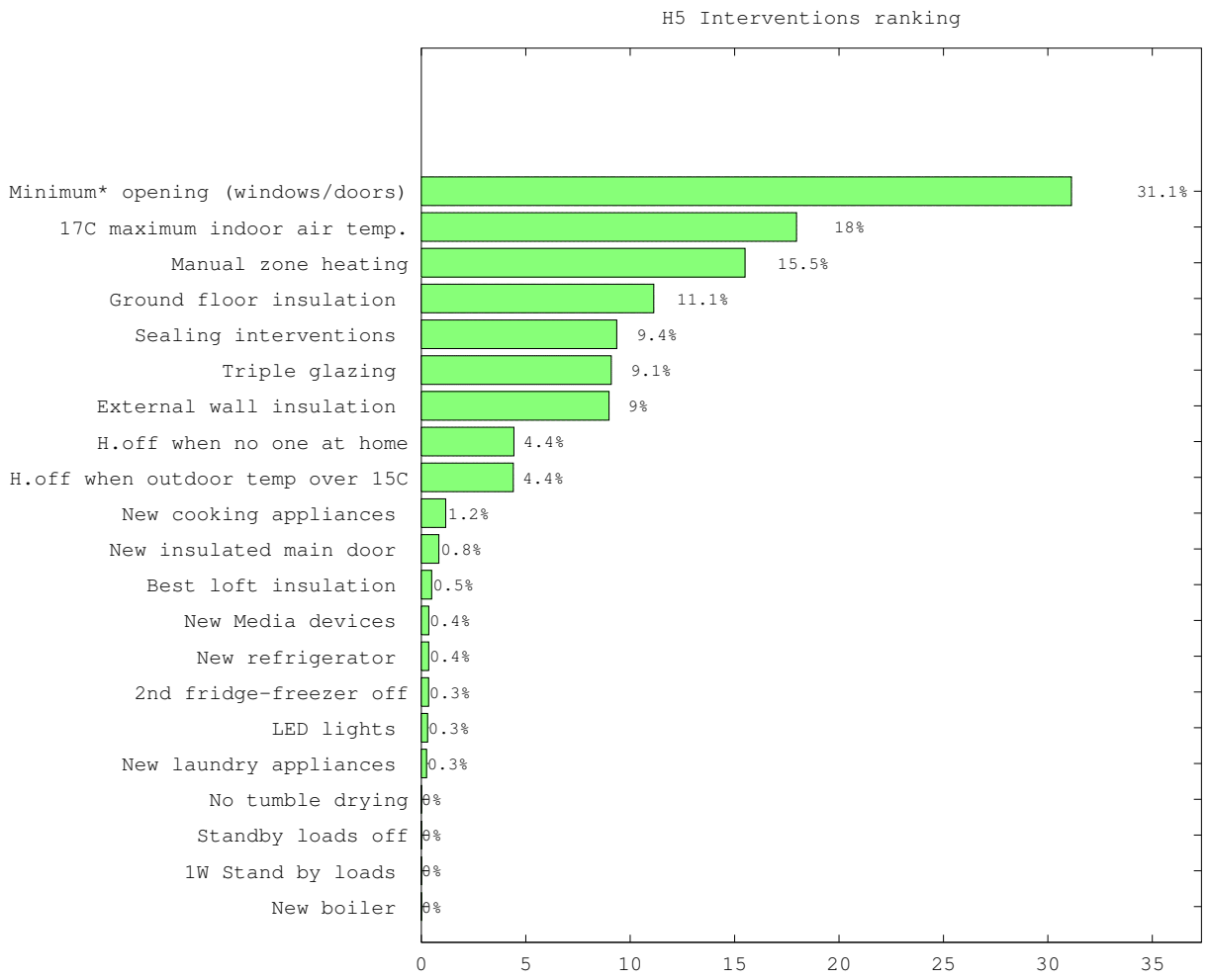

Figure A.3: The plot showing the rank order of the impact of reduction measures specific to each household, based on 12 months of monitoring data from their home in 2013.

- Are our findings very different to your first thoughts?

- Are our findings very different to your first thoughts?

- What do you think of each of the savings? Did any of them surprise you? If so why? 
Once the modelled measures were presented and compared to their initial ideas, it was asked if they would apply each measure or if only to a certain degree or under certain conditions. Also, it was asked if they would apply measures today (0-6 months), near future (1-5 years) or long term ( $>5$ years) and the reasons for their choices.

To finish with the interview, they were asked about the clarity of the information given and how it changed their initial views. Also, it was discussed how smart home technologies could help the implementation of energy reduction measures. Further details can be found at (Cosar-Jorda, 2017). 